\title{
Optimized procedures for manganese-52: Production, separation and radiolabeling
}

\author{
Fonslet, Jesper; Tietze, Sabrina; Jensen, Andreas Tue Ingemann; Graves, Stephen A.; Severin, Gregory
}

\section{Published in:}

Applied Radiation and Isotopes

Link to article, DOI:

10.1016/j.apradiso.2016.11.021

Publication date:

2017

Document Version

Peer reviewed version

Link back to DTU Orbit

Citation (APA):

Fonslet, J., Tietze, S., Jensen, A. T. I., Graves, S. A., \& Severin, G. (2017). Optimized procedures for manganese-52: Production, separation and radiolabeling. Applied Radiation and Isotopes, 121, 38-43. https://doi.org/10.1016/j.apradiso.2016.11.021

\section{General rights}

Copyright and moral rights for the publications made accessible in the public portal are retained by the authors and/or other copyright owners and it is a condition of accessing publications that users recognise and abide by the legal requirements associated with these rights.

- Users may download and print one copy of any publication from the public portal for the purpose of private study or research.

- You may not further distribute the material or use it for any profit-making activity or commercial gain

- You may freely distribute the URL identifying the publication in the public portal 
Optimized Procedures for Production, Separation and Labeling of Manganese-52 Jesper Fonslet ${ }^{1}$, Sabrina Tietze ${ }^{1}$, Andreas I. Jensen ${ }^{1}$, Stephen A. Graves ${ }^{2}$, Gregory W. Severin ${ }^{1 *}$

${ }^{1}$ Hevesy Laboratory, Center for Nuclear Technologies at the Technical University of Denmark, Frederiksborgvej 399, 4000 Roskilde, Denmark.

${ }^{2}$ Department of Medical Physics, University of Wisconsin - Madison, Madison, Wisconsin 53706, United States

*Correspondence email: gwseverin@chemistry.msu.edu

\begin{abstract}
Pressed chromium-powder cyclotron targets were irradiated with $16 \mathrm{MeV}$ protons, producing ${ }^{52} \mathrm{Mn}$ with average yields of $6.2 \pm 0.8 \mathrm{MBq} / \mu \mathrm{Ah}$. Separation by solid-phase anion exchange from ethanol-HCl mixtures recovered $94.3 \pm 1.7 \%$ of ${ }^{52} \mathrm{Mn}$ and reduced the chromium content by a factor of $2.2 \pm 0.4 \times 10^{5}$. An additional AG 1-X8 column was used to remove copper, iron, cobalt and zinc impurities from the prepared ${ }^{52} \mathrm{Mn}$ in $8 \mathrm{M} \mathrm{HCl}$. The macrocyclic chelator DOTA was rapidly radiolabeled with ${ }^{52} \mathrm{Mn}$ in aq. ammonium acetate ( $\mathrm{pH} 7.5$ R.T.) with a radiochemical yield $>98 \%$ within 1 minute and was stable for $>2$ days in bovine serum. The improved separation and purification methodology facilitates the use of ${ }^{52} \mathrm{Mn}$ in basic science and preclinical investigations.
\end{abstract}

Keywords: Manganese, Mn-52, PET, DOTA, serum stability, cyclotron, isotope production

\title{
Introduction
}

Manganese is an element essential to living organisms in which it functions as a co-factor in a wide variety of enzymes in its divalent state $^{2} . \mathrm{Mn}^{2+}$ enters neurons via voltage gated $\mathrm{Ca}^{2+}$ channels and has, due to its paramagnetic properties, been used preclinically as a potent MRI contrast agent for imaging neural activity ${ }^{3}$. In addition, it has been established that manganese enters active beta cells in the islets of Langerhans, thus providing the possibility of a non-invasive measure of the functional beta cell mass during the progression of diabetes ${ }^{4}$.

Manganese, however, is toxic and the maximum amount of injected MRI contrast is therefore severely limited $^{5-7}$. This fact has hindered the use of manganese enhanced MRI (MEMRI) in clinical investigations. However, the already well established methods developed in preclinical MEMRI can be readily adapted to Positron Emission Tomography (PET) by using ${ }^{52 \mathrm{~g}} \mathrm{Mn}$ (from here on ${ }^{52} \mathrm{Mn}, \mathrm{t}_{1 / 2}=5.6$ days; $\beta^{+}=29.4 \%$; $\mathrm{E}_{\text {ave } \beta+}$ 
$=242 \mathrm{keV}$ ), for which sub-nM concentrations are sufficient for functional imaging, thereby completely bypassing the toxicity issues of manganese.

Currently ${ }^{89} \mathrm{Zr}$ and ${ }^{64} \mathrm{Cu}$ are the common radiometals of choice for labeling proteins with slow distribution kinetics ${ }^{8,9}$. However, for some preclinical and basic science applications ${ }^{52} \mathrm{Mn}$ may be a better choice. It provides aqueous chelation chemistry similar to that of ${ }^{64} \mathrm{Cu}$, omitting the need for hard ligands like oxalate which are needed to keep ${ }^{89} \mathrm{Zr}$ chemically accessible, while having a higher $\beta^{+}$branch as well as a longer half-life than both ${ }^{64} \mathrm{Cu}\left(17.6 \% \beta^{+}, \mathrm{T}_{1 / 2}=12.7 \mathrm{~h}\right)$ and ${ }^{89} \mathrm{Zr}\left(22.7 \% \beta^{+}, \mathrm{T}_{1 / 2}=3.3\right.$ days $)$. In PET imaging of small animals, image resolution is a critical in order to allow discrimination of different regions of interest. The primary factor limiting the resolution is the energy of the emitted positron ${ }^{10}$. In principle, the lower average $\beta^{+}$energy of ${ }^{52} \mathrm{Mn}\left(242 \mathrm{keV}\right.$ for ${ }^{52} \mathrm{Mn}$ versus $396 \mathrm{keV}$ for ${ }^{89} \mathrm{Zr}$ ) will result in PET resolution superior to ${ }^{89} \mathrm{Zr}$.

Despite its facile chelation chemistry and attractive imaging properties, limited work has been reported on the separation chemistry and labeling with ${ }^{52} \mathrm{Mn}$. This is probably a consequence of the somewhat discouraging dosimetry associated with the multiple high energy, high abundance gamma emissions of ${ }^{52} \mathrm{Mn}$ (744, 936 and $1434 \mathrm{keV}$ ) as seen in figure 1. This, however, only has significance if the purpose of the study is translational tracer design. In drug development, the dosimetry is less relevant, because the radioisotope is not intended to be part of the final drug product, but only used as a means to gather crucial information about drug kinetics, biodistribution, route of metabolization and excretion, etc.

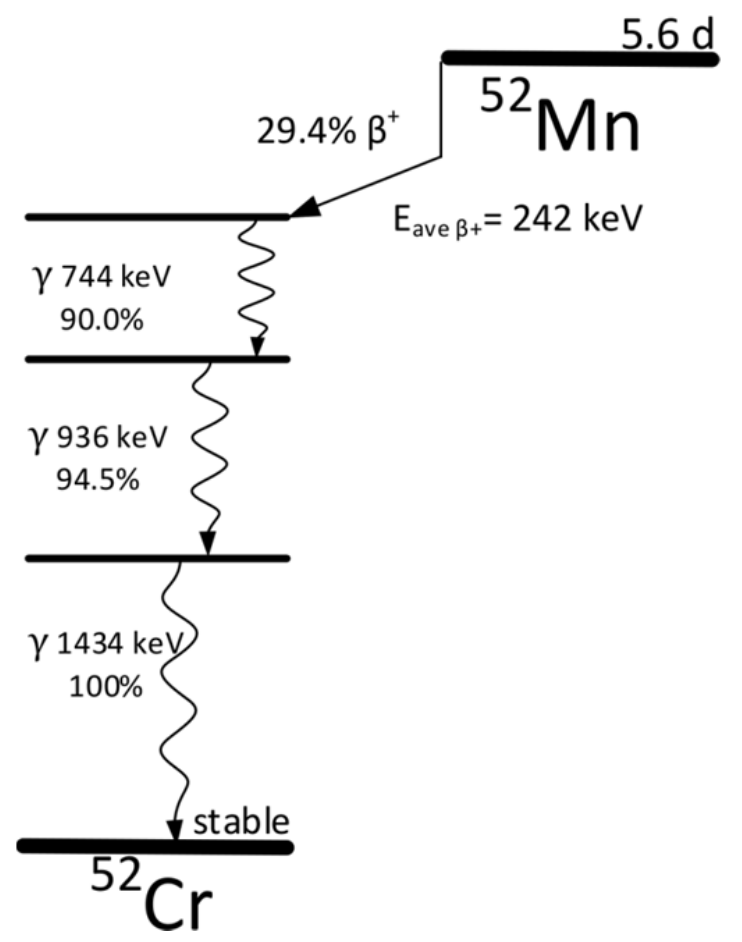

Figure 1: A simplified decay scheme for ${ }^{52 \mathrm{~g}} \mathrm{Mn}^{11}$.

Detailed work on production cross-sections of the ${ }^{\text {nat }} \mathrm{Cr}(\mathrm{p}, \mathrm{x})^{52} \mathrm{Mn}$ reaction has demonstrated that the reaction is highly capable of providing sufficient amounts of ${ }^{52} \mathrm{Mn}$ for imaging applications ${ }^{12,13}$. Recently, Buchholz 
et al. reported a separation method based on solid phase extraction of manganese from acid/organic solvent mixtures ${ }^{14}$. The results presented in the present study are an improvement on a conceptually similar method recently published by this group ${ }^{1}$, demonstrating improved separation efficiency without compromising the decrease in chromium content. One major improvement on previously published work is the introduction of a remediation column, which efficiently removes non-radioactive metal-ion impurities that would otherwise hinder high specific activity labeling. The improved method is still time efficient and can be performed in less than $4 \mathrm{~h}$. Additionally, optimized labeling conditions with the chelator DOTA $(1,4,7,10$ tetraazacyclododecane-1,4,7,10-tetraacetic acid) and the bioconjugate DOTA-(Tyr ${ }^{3}$ )-octreotate (DOTATATE) are explored and reported. Serum stability studies of the ${ }^{52} \mathrm{Mn}$-DOTA complex demonstrate the suitability of the chelator for in vivo studies.

The work presented in this paper describes tested and optimized procedures for production and purification, as well as labeling with ${ }^{52} \mathrm{Mn}$ produced on a small medical cyclotron.

\section{Materials and Methods}

\section{General experimental details}

Unless otherwise stated, all chemicals were purchased from Sigma Aldrich. Chromium powder (100 - 325 mesh, 99.99\% purity) was obtained from Alfa-Aesar. Hydrochloric acid (aq. $\mathrm{HCl} \geq 37 \%$, TraceSelect, Fluka) was titrated and found to be $11.3 \mathrm{M}$. All other concentrations of $\mathrm{HCl}$ used, were prepared from this batch by dilution with TraceSELECT water (Fluka). All other water was Milli-Q grade (Sartorius Arium 611VF, $\sigma=$ $0.055 \mu \mathrm{S} / \mathrm{cm})$.

$100 \mathrm{~g}$ of AG 1-X8 anion exchange resin in the formate form (8\% cross-linked with divinyl benzene, 200 400 mesh, Bio-Rad) was converted to its chloride form by rinsing with 20 bed volumes of $2 \mathrm{M}$ aq. $\mathrm{HCl}$ and washing with Milli-Q water until the effluent was neutral $\mathrm{pH}$. Afterwards the resin was washed with ethanol $\left(\geq 99.8 \%\right.$, Fluka) and dried at $20^{\circ} \mathrm{C}$.

Thin-layer chromatography (TLC) was performed on aluminum-backed silica (Merck TLC silica gel 60 F254) and eluted with $5 \%(\mathrm{w} / \mathrm{v})$ ammonium acetate in a 1:1 mixture of methanol and water. In this system, the $\mathrm{R}_{\mathrm{f}}$ values were determined to be $0.30-0.35$ for Mn-DOTA and 0.4-0.5 for Mn-DOTA-TATE, while unchelated $\mathrm{Mn}^{2+}$ remains at the origin. TLC plates were analyzed by autoradiography on a Cyclone Plus Storage Phosphor Scanner (PerkinElmer) and data analysis was performed using the OptiQuant software (PerkinElmer).

${ }^{52} \mathrm{Mn}$ samples in excess of $1 \mathrm{MBq}$ were quantified with a Capintec CRC-55tR dose calibrator using the manufacturer's recommended calibration number "676/2". Low activity samples of ${ }^{52} \mathrm{Mn},{ }^{54} \mathrm{Mn}$, and all ${ }^{51} \mathrm{Cr}$ samples were quantified using either liquid scintillation counting (LSC) on a HIDEX 300 SL or by gamma spectroscopy a Ge(Li) detector (Princeton Gammatech LGC 5) calibrated using certified ${ }^{133} \mathrm{Ba}$ and ${ }^{152} \mathrm{Eu}$ 
calibration standards. The obtained gamma spectra were processed using the Genie 2000 software (Canberra).

Trace metals were quantified by ICP-OES (inductively coupled plasma optical emission spectroscopy) using a ThermoScientific iCAP 6000 Series instrument with iTeva software. The spectrometer was calibrated against standard solutions containing $\mathrm{Cr}, \mathrm{Mn}, \mathrm{Co}, \mathrm{Fe}, \mathrm{Zn}$ and $\mathrm{Cu}$, which were prepared by dissolution and dilution of chloride salts of the tested metals in $0.3 \mathrm{M} \mathrm{HCl}$. Samples for analysis were likewise diluted in 0.3 $\mathrm{M} \mathrm{HCl}$.

\section{Cyclotron targetry and irradiation}

The targets were prepared by pressing $90-273 \mathrm{mg}$ of chromium powder onto the surface of a $1 \mathrm{~mm}$ thick $\varnothing=$ $29 \mathrm{~mm}$ silver disc using a metal powder pressing mold, ensuring centering of the $\varnothing=13 \mathrm{~mm}$ pressed chromium pellets. The pressing was done using a mechanical press at $7500 \mathrm{~kg} / \mathrm{cm}^{2}$ of pressure $(10000 \mathrm{~kg}, \varnothing$ $=13 \mathrm{~mm}$ ) resulting in approximate target thicknesses in the range of $68-206 \mathrm{mg} / \mathrm{cm}^{2}$. The disc was covered with an either $12.5 \mu \mathrm{m}$ or $25 \mu \mathrm{m}$ niobium front foil and mounted on a beam port on a GE PETtrace 800 cyclotron, providing direct water cooling on the rear face of the silver disc. The target was irradiated at a beam current of $20 \mu \mathrm{A}$ with an incident energy of $16 \mathrm{MeV}$ for $80-400$ minutes resulting in integrated currents of $28-128 \mu \mathrm{Ah} .{ }^{52} \mathrm{Mn}$ was produced primarily via the ${ }^{52} \mathrm{Cr}(\mathrm{p}, \mathrm{n}){ }^{52} \mathrm{Mn}$ reaction, with a small contribution from the less abundant ${ }^{53} \mathrm{Cr}$ via ${ }^{53} \mathrm{Cr}(\mathrm{p}, 2 \mathrm{n})^{52} \mathrm{Mn}$, by proton irradiation of naturally abundant chromium. The $2.36 \%$ abundant ${ }^{54} \mathrm{Cr}$ gave rise to co-production of small amounts of ${ }^{54} \mathrm{Mn}$ via the ${ }^{54} \mathrm{Cr}(\mathrm{p}, \mathrm{n}){ }^{54} \mathrm{Mn}$ reaction.

\section{Determination of separation conditions}

In order to determine the optimal acid:ethanol ratio for selective solid phase extraction of manganese from chromium onto AG 1-X8 resin, distribution coefficients of $\mathrm{Cr}^{3+}$ and $\mathrm{Mn}^{2+}$ on $\mathrm{AG}$ 1-X8 were determined in mixtures of aqueous $\mathrm{HCl}$ (conc. range: $3.8-11.3 \mathrm{M}$ ) and absolute ethanol, mixed in a range of 2-7\% (v/v) aq. $\mathrm{HCl}$ in ethanol. A total of 18 different conditions were tested by adding $100 \pm 2 \mathrm{mg}$ of AG 1-X8 resin to 5 $\mathrm{mL}$ of each of the acid:ethanol ratios, all containing $100 \mathrm{kBq}{ }^{52} \mathrm{Mn}$ and $250 \mu \mathrm{g}{ }^{\text {nat }} \mathrm{Cr}$. The resulting mixtures were agitated periodically over the course of several hours at room temperature, and after settling for $72 \mathrm{~h}$ they were re-agitated and finally allowed to settle for a further hour. $100 \mu \mathrm{L}$ samples of the supernatants were removed for measurement by ICP-OES to determine the Cr-content and liquid scintillation counting to determine the ${ }^{52} \mathrm{Mn}$ content. The data were analyzed by comparison to $\mathrm{Cr}$ and ${ }^{52} \mathrm{Mn}$ containing standards prepared without resin. 


\section{Separation}

Following bombardment, the irradiated target was left on the cyclotron for at least 2 hours to allow the decay of ${ }^{52 \mathrm{~m}} \mathrm{Mn}\left(t_{1 / 2}=20 \mathrm{~min}\right)$. After disassembling the target holder, the target disc was submerged in $11.3 \mathrm{M} \mathrm{HCl}$ and either left overnight at room temperature or on a heating block at $90-100{ }^{\circ} \mathrm{C}$ for approx. 30 min to dissolve the chromium. The entire dissolution was taken almost to dryness at $150{ }^{\circ} \mathrm{C}$ (either with or without nitrogen flow) and redissolved in aq. $\mathrm{HCl}(1.5 \mathrm{~mL}, 11.3 \mathrm{M}$. This solution was diluted in absolute ethanol (48.5 mL), bringing the final concentration to $3 \%(\mathrm{v} / \mathrm{v}) 11.3 \mathrm{M} \mathrm{HCl}$ in absolute ethanol. This was led through a thin $(\varnothing=4 \mathrm{~mm})$ AG 1-X8 column (300 mg), equilibrated by washing with $5 \mathrm{ml} 0.1 \mathrm{M} \mathrm{HCl}, 10 \mathrm{~mL}$ water and $5 \mathrm{~mL}$ of $3 \%(\mathrm{v} / \mathrm{v}) 11.3 \mathrm{M} \mathrm{HCl}$ in absolute ethanol, retaining the ${ }^{52} \mathrm{Mn}$ on the column. The loaded column was washed with $25 \mathrm{~mL}$ of $3 \%(\mathrm{v} / \mathrm{v}) 11.3 \mathrm{M} \mathrm{HCl}$ in absolute ethanol and the ${ }^{52} \mathrm{Mn}$ was eluted in $2 \mathrm{~mL}$ of 0.1 $\mathrm{M} \mathrm{HCl}$. This entire procedure was then repeated twice for a total of three iterations (figure 2). In the second and third iteration however, the dry activity was redissolved in only $300 \mu \mathrm{L} 11.3 \mathrm{M} \mathrm{HCl}$ and mixed with 9.7 $\mathrm{mL}$ of absolute ethanol. Because of the markedly reduced overall metal content after the first column, the resin mass used in the second and third column was reduced to $200 \mathrm{mg}$ and $100 \mathrm{mg}$, respectively. 


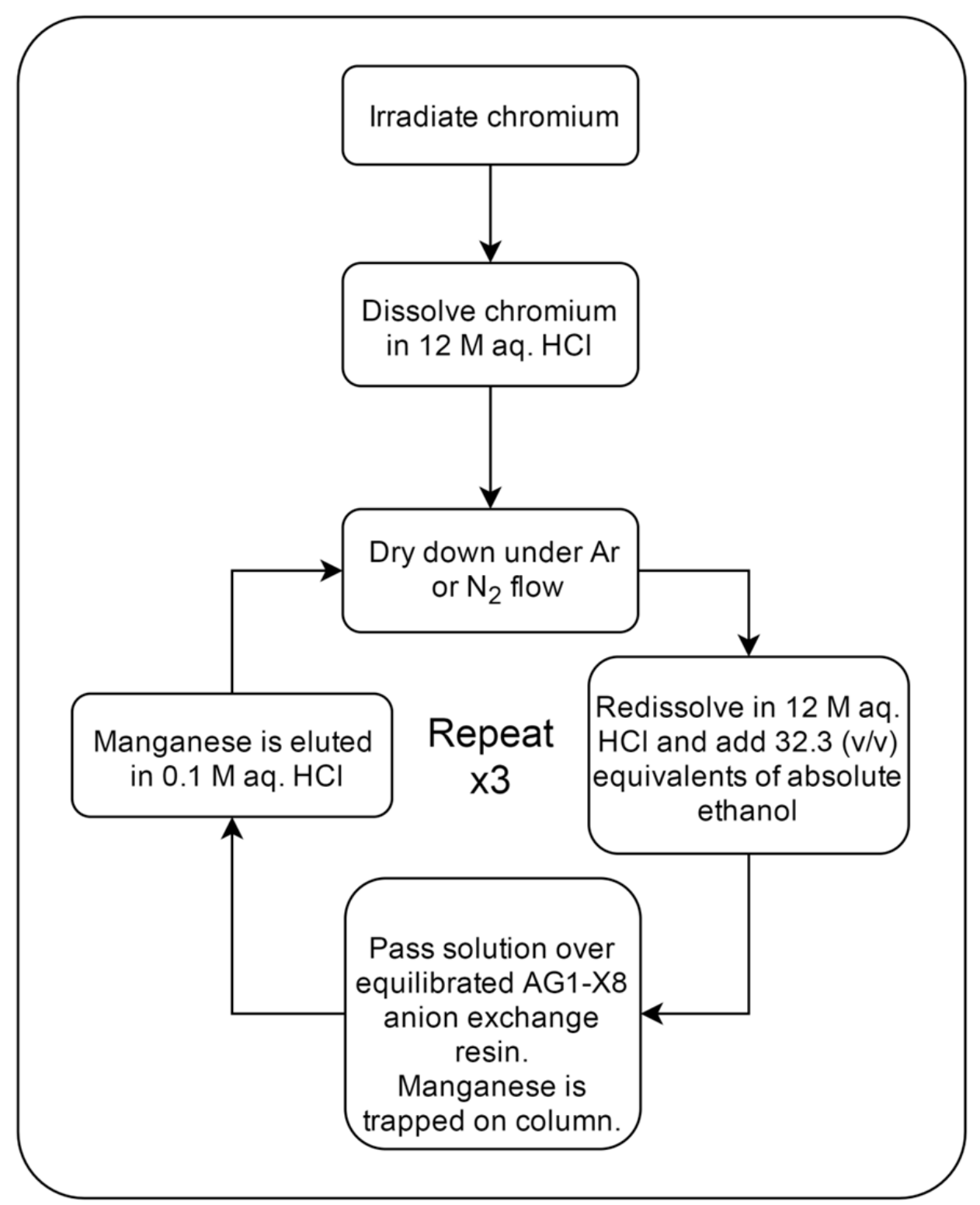

Figure 2: Flowchart illustrating the separation process.

\section{Trace Metal Content and Remediation}

After each separation repetition, samples were taken for ICP-OES analysis to determine the separation efficiency. The analytical concentrations of chromium and manganese were determined, as well as the common impurities iron, copper, cobalt, and zinc. $50 \mu \mathrm{L}$ or $100 \mu \mathrm{L}$ of sample material were diluted to $5-10$ $\mathrm{mL}$ with $0.3 \mathrm{M} \mathrm{HCl}$ in $15 \mathrm{~mL}$ metal free PP centrifuge tubes (VWR) before analysis. The separation efficiency was determined from the calculated chromium content. The specific activity was calculated using the Mn content as determined by ICP-OES.

As contaminant metals will vary depending on target material and reagent stocks, we implemented a short procedure for removal of the unwanted metal ions of iron, zinc, copper, and cobalt. For this procedure, a 
sample of ${ }^{52} \mathrm{Mn}$ (in $0.1 \mathrm{M} \mathrm{HCl}$ ) from after the third separation column, was dried down and then redissolved in $1 \mathrm{~mL} 8 \mathrm{M} \mathrm{HCl}$. This was passed over $500 \mathrm{mg}$ AG 1-X8 resin (pre-equilibrated in $8 \mathrm{M} \mathrm{HCl}$ ) and the effluent containing the ${ }^{52} \mathrm{Mn}$, along with a wash volume of an additional $2 \mathrm{~mL}$ of $8 \mathrm{M} \mathrm{HCl}$, were collected and the metal content determined using ICP-OES.

\section{Chelation chemistry}

${ }^{52} \mathrm{Mn}$ in $0.1 \mathrm{M} \mathrm{HCl}$ was dried on a heating block under a stream of either argon or nitrogen (5-7 minutes at $\left.130{ }^{\circ} \mathrm{C}\right)$. When cooled to ambient temperature, a solution of DOTA in aq. ammonium acetate buffer $(1.00$ $\mathrm{mL}$, DOTA: $50 \mu \mathrm{M}$, ammonium acetate: $100 \mathrm{mM}$ ), adjusted to $\mathrm{pH} 4.5,6.0$ or 7.5 using $\mathrm{HCl} / \mathrm{NaOH}$, was added to the dry ${ }^{52} \mathrm{Mn}$. The resulting mixtures were stirred at either room temperature (RT) or $55{ }^{\circ} \mathrm{C}$ and analyzed at specified time-points by radio-TLC. In addition, after $15 \mathrm{~min}$ or $30 \mathrm{~min}$, one tenth of the volume $(100 \mu \mathrm{L})$ was removed and the aspirated radioactivity was compared to the radioactivity left in the vial, in order to confirm that all of the ${ }^{52} \mathrm{Mn}$ was present in the aqueous phase. Under identical conditions, solutions of DOTA-TATE in ammonium acetate buffer (1.00 mL, DOTA-TATE: $50 \mu \mathrm{M}$, ammonium acetate $100 \mathrm{mM}$, $\mathrm{pH}=7.4$ ) were added to vials containing dry ${ }^{52} \mathrm{Mn}$ and the reactions were monitored over time using radioTLC.

\section{Serum stability}

Two vials containing purified ${ }^{52} \mathrm{Mn}$ in $0.1 \mathrm{M} \mathrm{HCl}$ were dried under nitrogen flow at $130{ }^{\circ} \mathrm{C}$. After cooling to room temperature, the ${ }^{52} \mathrm{Mn}$ in one vial was redissolved in isotonic HEPES buffer (10 mM HEPES, $150 \mathrm{mM}$ $\mathrm{NaCl}, \mathrm{pH}=7.4$ ) to a radioactivity concentration of $13 \mathrm{MBq} / \mathrm{mL}$. The ${ }^{52} \mathrm{Mn}$ in the other vial was redissolved in isotonic HEPES buffer containing $25 \mu \mathrm{M}$ DOTA, likewise to a concentration of $13 \mathrm{MBq} / \mathrm{mL}$. Radio-TLC after 5 minutes confirmed that all ${ }^{52} \mathrm{Mn}$ in the DOTA-containing solution was present as Mn-DOTA. Using $100 \mu \mathrm{L}$ aliquots of these stocks, four different $1 \mathrm{~mL}$ preparations of ${ }^{52} \mathrm{Mn}$ were produced by dilution with whole fetal bovine serum (Sigma Aldrich) and isotonic HEPES buffer: ${ }^{52} \mathrm{Mn}$-DOTA in $75 \%$ bovine serum, ${ }^{52} \mathrm{Mn}$ in $75 \%$ bovine serum, ${ }^{52} \mathrm{Mn}$-DOTA in isotonic HEPES buffer and ${ }^{52} \mathrm{Mn}$ in isotonic HEPES buffer. After incubation at $37{ }^{\circ} \mathrm{C}$ for 2 days, the mixtures were applied to PD-10 size exclusion cartridges (GE Healthcare), eluted with isotonic HEPES and collected in $1 \mathrm{~mL}$ fractions. The radioactivity in the collected fractions was measured, and the peak fractions from the DOTA-containing samples were analyzed by radioTLC to assess whether the Mn-DOTA complex was still intact. 


\section{Results}

\section{Cyclotron targetry and irradiation}

None of the irradiated targets showed visible signs of thermal damage after irradiation. The production yields for ${ }^{52} \mathrm{Mn}$ ranged from 4.87-7.43 $\mathrm{MBq} / \mu \mathrm{Ah}$, while ${ }^{51} \mathrm{Cr}$ production rates ranged from $0.29-0.39 \mathrm{MBq} / \mu \mathrm{Ah}$. Considering that ${ }^{52 \mathrm{~m}} \mathrm{Mn}$ has a very short half-life and that ${ }^{51} \mathrm{Cr}$ is separated along with the bulk ${ }^{\text {nat }} \mathrm{Cr}$, the only isotope that could appear as a contaminant after purification is ${ }^{54} \mathrm{Mn}\left(\mathrm{T}_{1 / 2}=312.1\right.$ days), which was produced at an approximate rate of $7.4 \mathrm{kBq} / \mu \mathrm{Ah}$.

\section{Determination of separation conditions}

Batch mode experiments were performed to determine the distribution coefficients of both $\mathrm{Mn}^{2+}$ and $\mathrm{Cr}^{3+}$ on the anion exchange resin $\mathrm{AG} 1-\mathrm{X} 8$ in a range of 2-7\% (v/v) 3.8-11.3 M HCl in absolute ethanol (figure 2). The measurements revealed an increase in $\mathrm{Mn}^{2+}$ extraction with increasing ethanol concentration as well as with increasing molarity of the acid. Under many of the conditions sampled, the measured distribution coefficient of manganese exceeded $1000 \mathrm{~mL} / \mathrm{g}$, which is sufficiently high to design trap-and-release

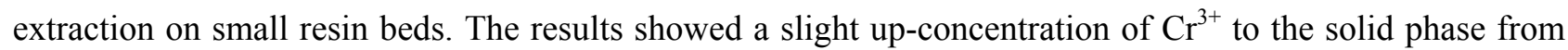
the solvent mixture, but always in a range of $0.5-10 \mathrm{~mL} / \mathrm{g}$ (figure 2).

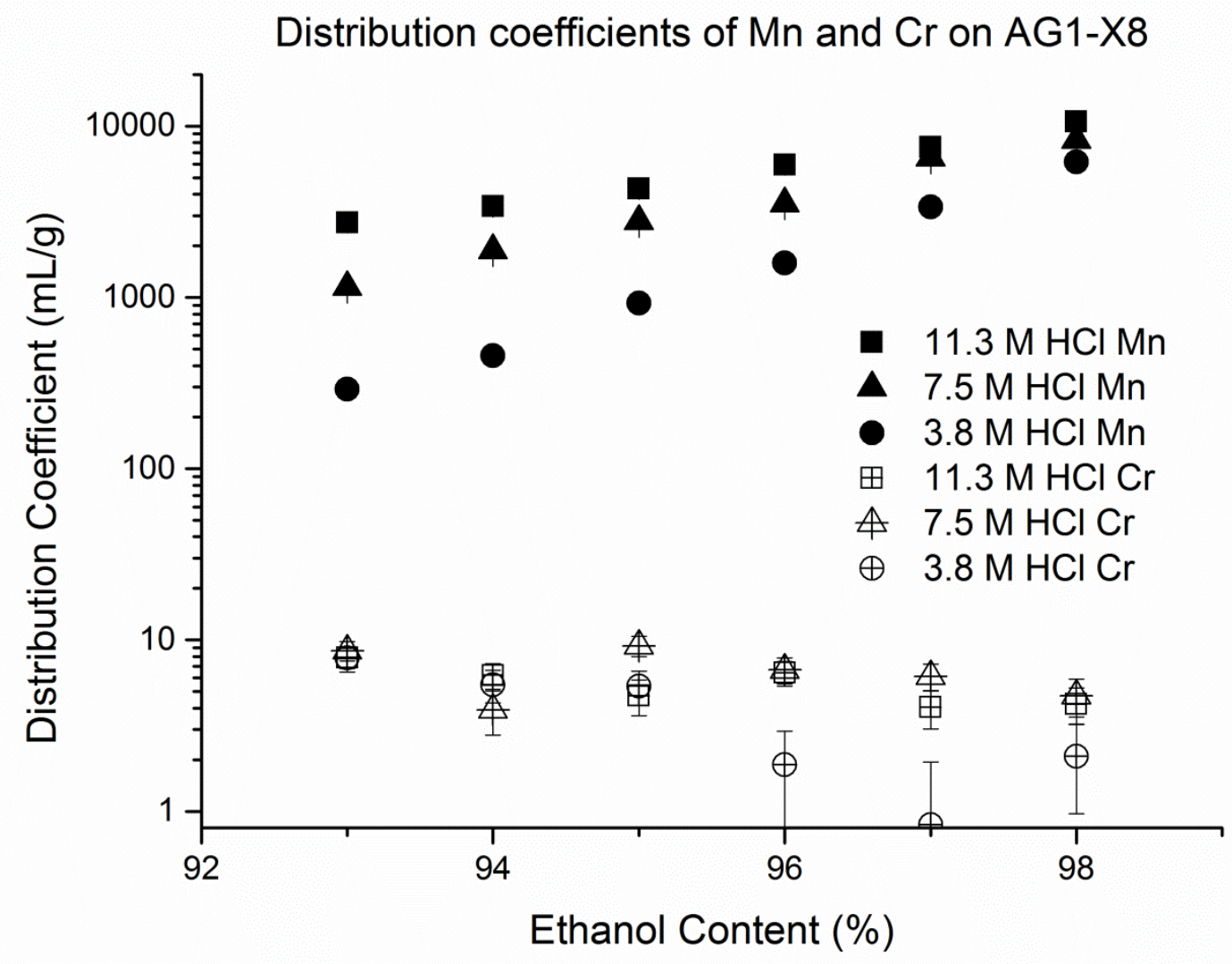


Figure 2. Graph showing the distribution coefficients for $\mathrm{Mn}^{2+}$ (solid markers) and $\mathrm{Cr}^{3+}$ (open markers) on AG 1-X8 resin from ethanol with various volumes and concentrations of aqueous hydrochloric acid. The $\mathrm{x}-$ axis percentage is $\mathrm{v} / \mathrm{v}$, with the complementary volume comprised of $11.3,7.5$, or $3.8 \mathrm{M}$ aq. $\mathrm{HCl}$.

\section{Separation}

Dissolution of the chromium target in $11.3 \mathrm{M} \mathrm{HCl}$ was very slow at room temperature, but was greatly accelerated with heat. Depending on laboratory logistics for the experiments, target dissolutions were either heated or not, with no observed disruption of the further chemical separation. Drying the dissolved target was time consuming, but was accelerated with nitrogen gas flow. The main purpose of drying the target was to obtain a reproducible acid and water content in the separation, and was found necessary to keep the processing volume small. It was important at this step not to dry the target material entirely, but to retain it as sludge in order to hasten redissolution. Redissolution with $11.3 \mathrm{M} \mathrm{HCl}$ was aided by heat, and at the first step was $>99.5 \%$ efficient at re-suspending the ${ }^{52} \mathrm{Mn}$ radioactivity. In preliminary experiments, attempts were made to redissolve the dry target mass directly in $3 \%(\mathrm{v} / \mathrm{v}) 11.3 \mathrm{M} \mathrm{HCl}$ in absolute ethanol, but this proved unsuccessful.

In the three repetitions of the AG 1-X8 purification, trapping of ${ }^{52} \mathrm{Mn}$ on $\mathrm{AG} 1-\mathrm{X} 8$ was quantitative, with $>99.8 \%$ of the available activity present on the column after washing. The ${ }^{52} \mathrm{Mn}$ was efficiently eluted $(>97 \%)$ in $2 \mathrm{~mL}$ of $0.1 \mathrm{M} \mathrm{HCl}$. After this, the ${ }^{52} \mathrm{Mn}$-containing solution was dried down in order to reset the acid and water content. The largest losses of ${ }^{52} \mathrm{Mn}$ were incurred when attempting to re-solubilize the residue, ranging from $0.5-2 \%$ losses at each of the two repetitions. Similar to the previous redissolution, we found that dissolution of dried down $\mathrm{Cr} / \mathrm{Mn}$, was sufficiently efficient in hot $11.3 \mathrm{M} \mathrm{HCl}$, but not possible in $3 \%(\mathrm{v} / \mathrm{v}) 11.3 \mathrm{M} \mathrm{HCl}$ in absolute ethanol. $94.3 \pm 1.7 \%$ of the produced activity was retained after the three purification iterations, with an average $\mathrm{Cr}^{3+}$ mass reduction factor of $2.2 \pm 0.4 \times 10^{5}$ to an average mass of only $607 \mathrm{ng}$, as determined by ICP-OES (figure 3). 


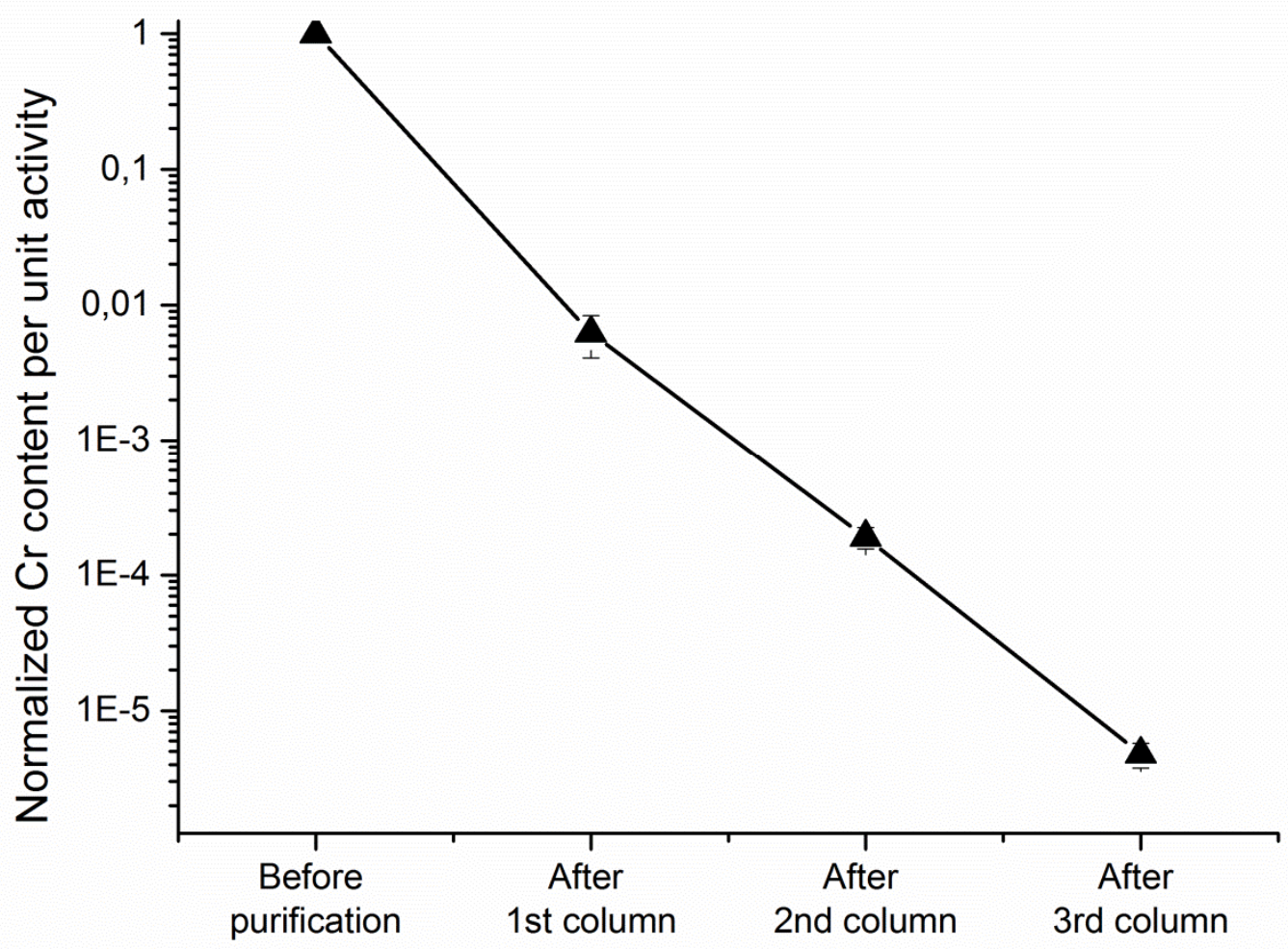

Figure 3: Reduction of the chromium content throughout the separation procedure $(n=3)$. Chromium content is given as chromium mass per unit activity of ${ }^{52} \mathrm{Mn}$, relative to the starting value. Therefore, the value shown on the plot for each step is the cumulative decontamination factor at the end of that step.

\section{Trace Metal Content and Remediation}

The specific activity of ${ }^{52} \mathrm{Mn}$ versus non-radioactive manganese content ranged from 16 to $120 \mathrm{GBq} / \mu \mathrm{mol}$. ICP-OES analysis was able to determine which metal impurities were able to follow manganese through the purification steps. Other than chromium, the main impurities observed by ICP-OES analysis were iron and copper along with zinc and cobalt. These were present in varying amounts on the order of 0.01-1 nmol of each per MBq of ${ }^{52} \mathrm{Mn}$, and could be removed by a final remediation step, in which the ${ }^{52} \mathrm{Mn}$ in $8 \mathrm{M} \mathrm{HCl}$ was passed over an AG 1-X8 column. As a result of this step, $17 \%$ of the ${ }^{52} \mathrm{Mn}$ remained on the AG 1-X8 column, while the remaining $83 \%$ was available for further use from the $8 \mathrm{M} \mathrm{HCl}$.

Figure 4 shows the content of metal impurities after elution at each step of the separation, and after the final remediation column, relative to the amount of each metal that was present after the first column. Clearly, copper and cobalt behave similar to $\mathrm{Mn}$ in the separation, which is not surprising in light of the data presented by Pietrzyk and Fritz, which shows that copper and cobalt have the highest affinity for AG 1-X8 from partially aqueous $\mathrm{HCl}$ solutions of any metals tested ${ }^{15}$. The sharp decline in the contaminant 
concentration after the final purification step is consistent with the general data from Nelson et al. for metal ions against strong anion exchange resin in aqueous $\mathrm{HCl}^{16}$.

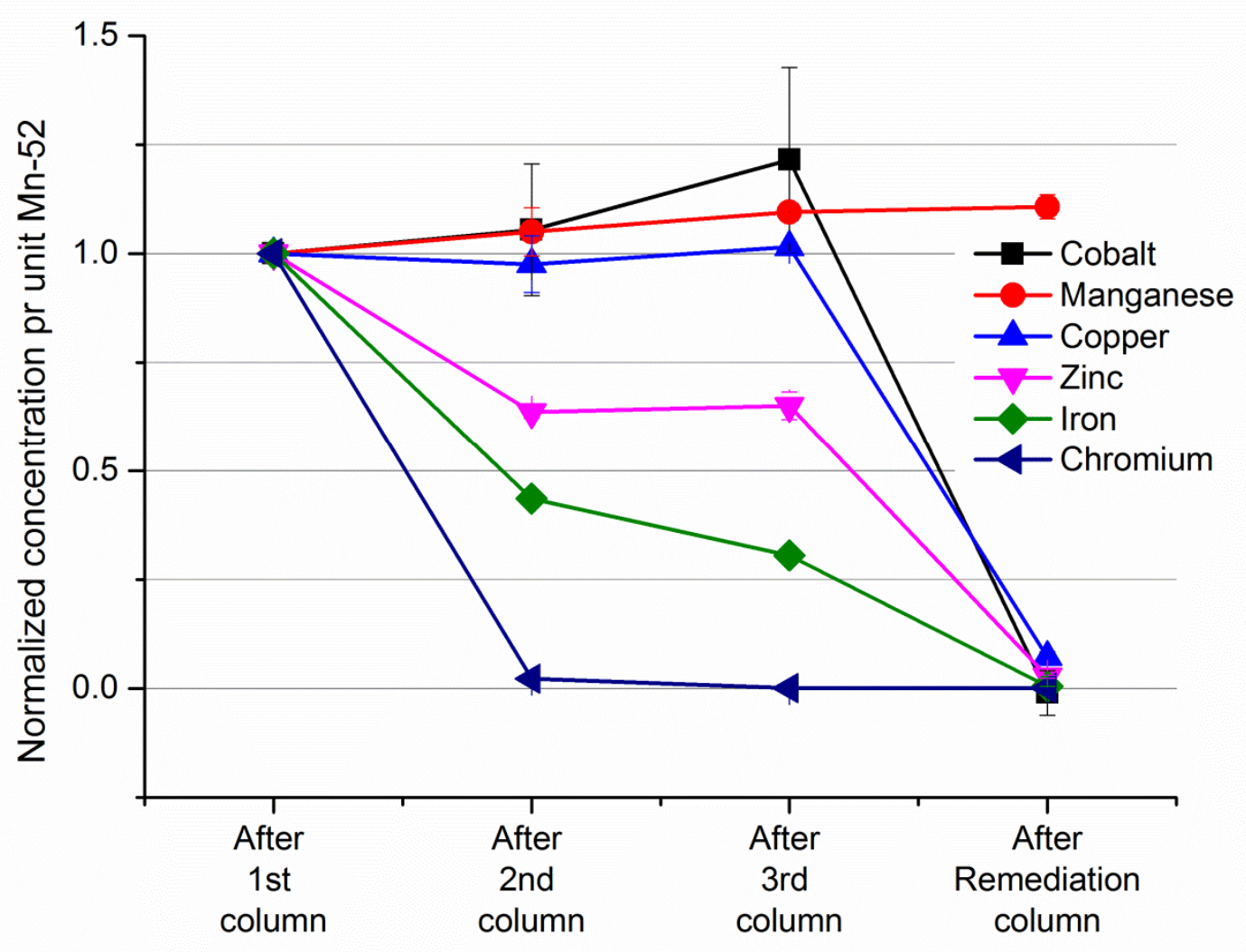

Figure 4: Trace metal behavior during the separation and after the remediation column. Values reflect the mass of each metal relative to ${ }^{52} \mathrm{Mn}$ radioactivity, normalized to the value after the first separation column. In this way, the curve for manganese shows that the specific activity of ${ }^{52} \mathrm{Mn}$ is slowly declining throughout the separation process. Evident in the plot is the effectiveness of the remediation column at removing many common transition metal impurities from the purified manganese.

\section{Chelation chemistry}

${ }^{52} \mathrm{Mn}$ was observed to be rapidly chelated by DOTA in a $\mathrm{pH}$ range of 4.5-7.5 and at both room temperature and $55{ }^{\circ} \mathrm{C}$ (figure 5). At $\mathrm{pH} 6.0$ and 7.5, ${ }^{52} \mathrm{Mn}$-DOTA was formed with $>99 \%$ conversion within one minute at both tested temperatures. At $\mathrm{pH} 4.5$ the conversion rate was slower, with $>99 \%$ conversion after 5 minutes at $55{ }^{\circ} \mathrm{C}$ and $>99 \%$ conversion after 20 minutes at room temperature. $>99 \%$ of the dried ${ }^{52} \mathrm{Mn}$ was resolubilized in the labeling buffer within 15 minutes in all observed cases, suggesting high solubility of $\mathrm{Mn}^{2+}$ at $\mathrm{pH}$ 4.5-7.5 in the tested buffer systems. Accordingly, our results show that ${ }^{52} \mathrm{Mn}$ is rapidly chelated by 
DOTA in the $\mathrm{pH}$ range of 4.5-7.5 and a temperature range of $20-55^{\circ} \mathrm{C}$. Similarly, the reactions with DOTATATE were efficient and reached $>99 \%$ completion after $10 \mathrm{~min}$ at room temperature.

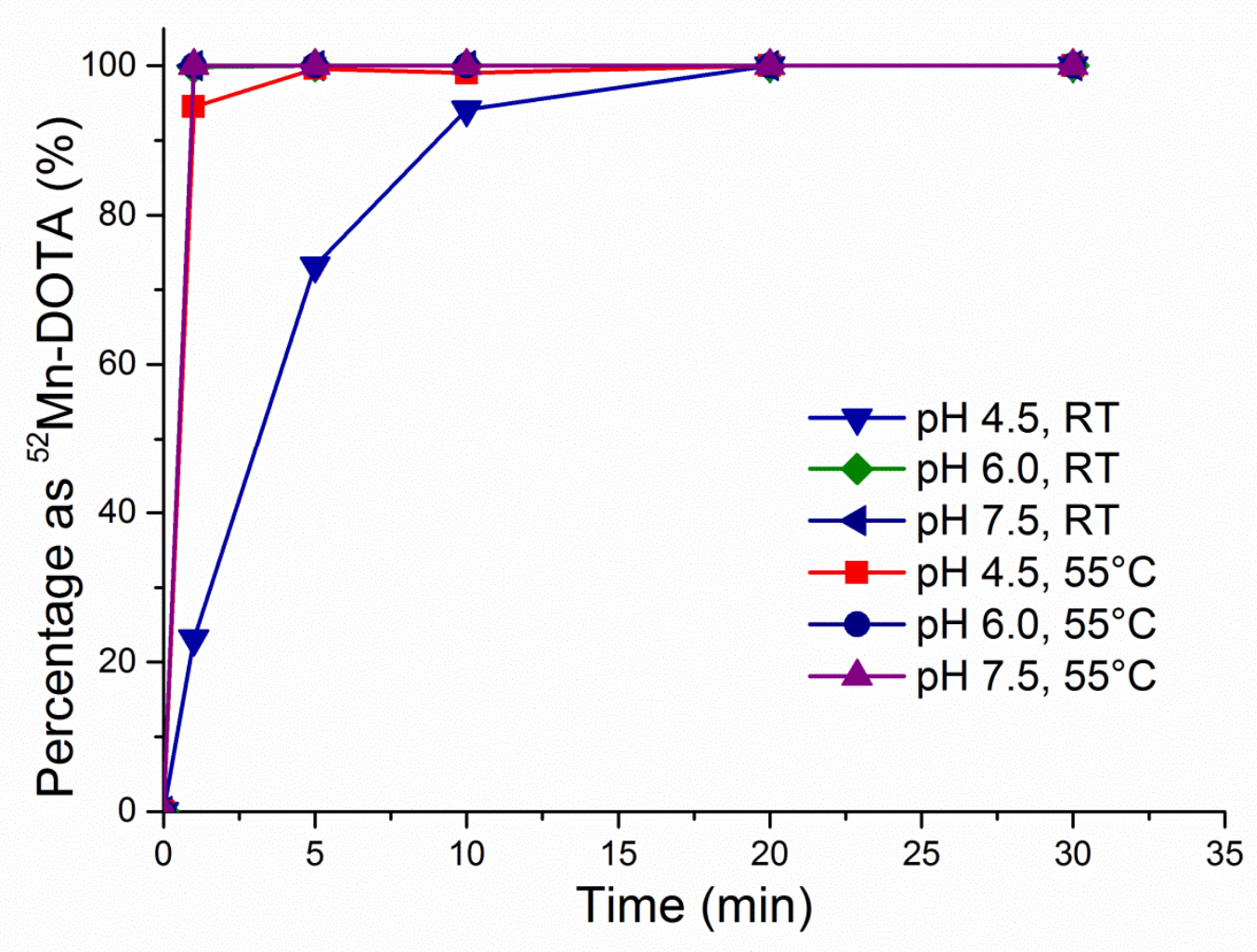

Figure 5: Chelation of $\mathrm{Mn}^{2+}$ by the macrocyclic chelate DOTA in ammonium acetate buffer for different $\mathrm{pH}$ values and temperature versus time.

\section{Serum Stability}

The serum stability test showed no indication of ${ }^{52} \mathrm{Mn}$-DOTA instability or transchelation of ${ }^{52} \mathrm{Mn}$ after 2 days in bovine serum. As the ${ }^{52} \mathrm{Mn}$-DOTA in bovine serum was eluted from the PD-10 column, the activity elution profile was identical to that of ${ }^{52} \mathrm{Mn}$-DOTA in isotonic HEPES buffer (figure 6). Subsequent radioTLC analysis of the eluted activity showed all activity present at the $\mathrm{R}_{\mathrm{f}}$ of ${ }^{52} \mathrm{Mn}$-DOTA, showing that all radioactivity was still in the form of ${ }^{52} \mathrm{Mn}$-DOTA. The PD-10 elution profiles of ${ }^{52} \mathrm{Mn}$-DOTA in bovine serum, ${ }^{52} \mathrm{Mn}$-DOTA in buffer, ${ }^{52} \mathrm{Mn}$ in bovine serum and ${ }^{52} \mathrm{Mn}$ in buffer can be seen in figure $6 .{ }^{52} \mathrm{Mn}$ mixed with bovine serum is observed to elute in the large-molecule fractions, while ${ }^{52} \mathrm{Mn}$ in buffer eluted in the small-molecule fractions. This indicated association of free ${ }^{52} \mathrm{Mn}$ with serum proteins. The elution profiles also provide an important reminder of the soft size separation cutoff of the PD-10 columns. Bioconjugation procedures commonly include a gel filtration step to remove unconjugated chelator before adding the radiometal to be labeled. If chelators are thought of as small molecules this could result in some amount of 
unconjugated chelator being collected in the protein fraction. This will necessarily result in lower labeling yields.

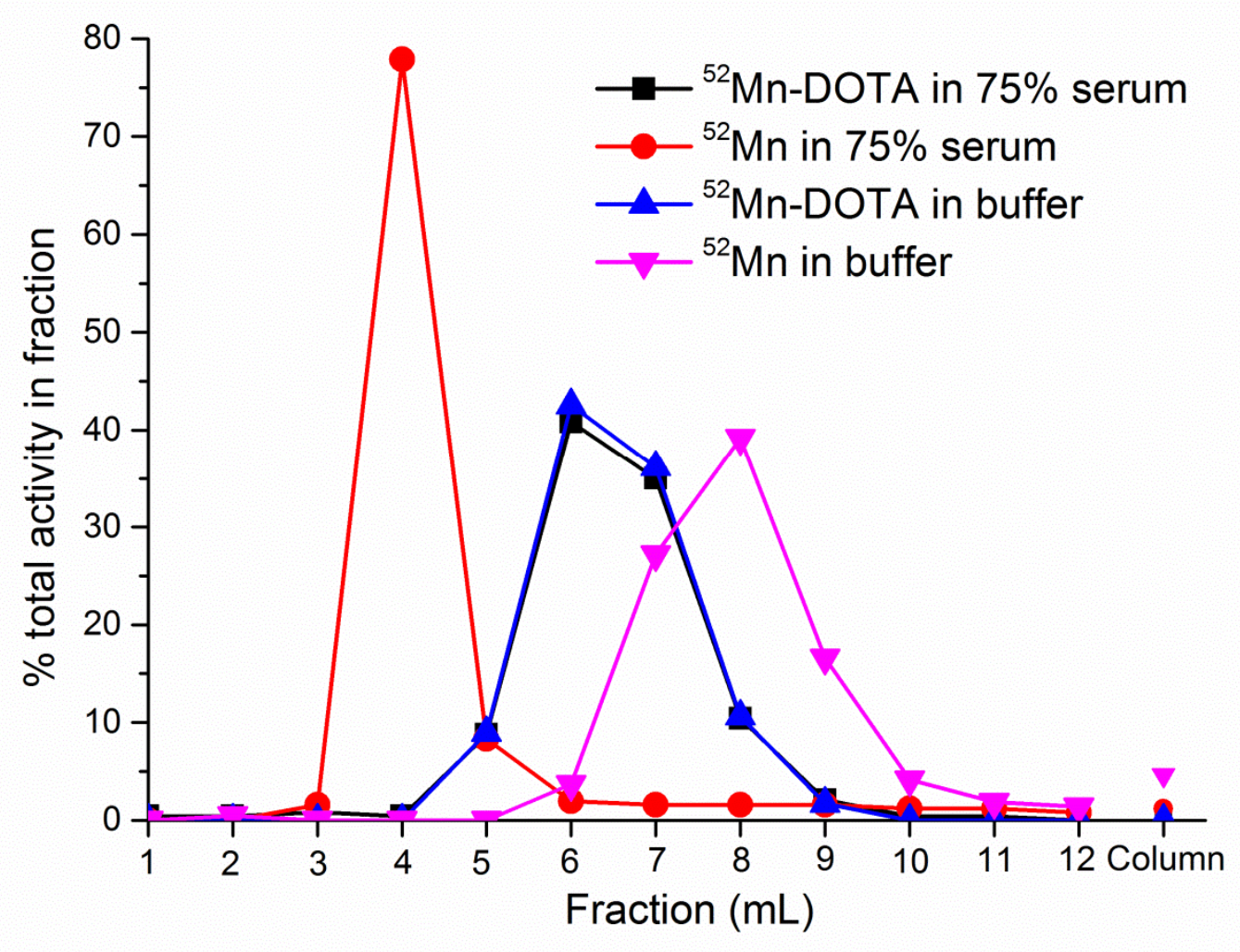

Figure 6: Gel filtration (PD-10) elution profile for ${ }^{52} \mathrm{Mn}$-DOTA and ${ }^{52} \mathrm{Mn}$ after incubation for two days at 37 ${ }^{\circ} \mathrm{C}$ with and without bovine serum. The plot documents how un-chelated activity while in serum will elute with the large molecule fractions, while when in buffer will elute with the small molecule fractions. ${ }^{52} \mathrm{Mn}$ dislocated from DOTA would elute in that manner, but that is not observed proving that the ${ }^{52} \mathrm{Mn}$-DOTA complex is intact.

\section{Discussion}

The methodology developed above is optimized for recovery of ${ }^{52} \mathrm{Mn}$ in a small volume of dilute $\mathrm{HCl}$. Improvements in ${ }^{52} \mathrm{Mn}$ extraction from the $\mathrm{Cr}$ matrix were made by employing sequentially smaller AG 1-X8 resin masses, using a controlled flow rate, and eluting in $0.1 \mathrm{M} \mathrm{HCl}$. Although the residual $\mathrm{Cr}^{3+}$ content in the final product is slightly higher compared to Graves et al. (reduction factor of $2.2 \pm 0.4 \times 10^{5}$ 
compared to $1.6 \pm 1.0 \times 10^{6}$ ), the amount is still sufficiently below toxic levels ${ }^{1}$. Overall, trap and release of ${ }^{52} \mathrm{Mn}$ using AG 1-X8 anion exchange resin is very efficient, and for the entire process, the largest losses of

${ }^{52} \mathrm{Mn}$ activity arose when redissolving the dried-down ${ }^{52} \mathrm{Mn}$ with $\mathrm{HCl}$. While, in principle this step could be avoided by eluting the columns with a higher concentration of $\mathrm{HCl}$, this would lead to excessively large volumes of ethanol/ $\mathrm{HCl}$ needed for further processing.

Overall, the column behavior agrees well with the measured distribution coefficients. The highest distribution coefficients for $\mathrm{Mn}^{2+}$ were observed at $2 \%$ (v:v) $11.3 \mathrm{M} \mathrm{HCl}$ in absolute ethanol with values of $1.06 \times 10^{4} \mathrm{~mL} / \mathrm{g}$. However, for the separation process, we selected $97 \%$ ethanol, because it afforded a more easy to handle volume of $\mathrm{HCl}$ for redissolving the dried ${ }^{52} \mathrm{Mn}$, while still keeping the required ethanol volume below $10 \mathrm{~mL}$ for the second and third separations. Also evident in the Mn distribution coefficients is a strong dependence on the $\mathrm{HCl}$ concentration, but given the overall high values for $97 \%$ ethanol with 7.5 and $11.3 \mathrm{M} \mathrm{HCl}$, the exact acid concentration seems to be unimportant. The behavior of $\mathrm{Cr}^{3+}$ in this system was shown to be relatively independent of the acid and ethanol concentrations. Contaminant metal ions of copper, zinc, cobalt and iron were observed to follow manganese through the separation process, but these were easily removed by a final cleanup step of passing the collected ${ }^{52} \mathrm{Mn}$ over an AG 1-X8 resin bed in $8 \mathrm{M}$ aq. $\mathrm{HCl}$. In instances where bioconjugate chelation can be subverted by competing metals, this extra step may prove essential.

Chelation reactions with DOTA were rapid over a wide $\mathrm{pH}$ range (4.5-7.5) when DOTA was present in large excess, and Mn-DOTA was shown to be $100 \%$ stable in bovine serum for $>2$ days. DOTA furthermore has very low affinity for $\mathrm{Cr}^{3+}$, which makes ${ }^{52} \mathrm{Mn}$ chelation with DOTA insensitive to residual trace $\mathrm{Cr}$ after separation. These three points support the use of DOTA as a chelator for stable chelation and bioconjugation of ${ }^{52} \mathrm{Mn}$ to long-circulating tracing vectors.

\section{Conclusion:}

The separation method for purifying ${ }^{52} \mathrm{Mn}$ from bulk chromium presented in this paper is robust, efficient, and easily adaptable depending upon need. Radiolabeling with the common bioconjugate chelator DOTA is rapid and serum stability of the DOTA chelate is excellent, making ${ }^{52} \mathrm{Mn}$ useful for extended time-point PET imaging for drug development and pharmacokinetic evaluations.

\section{Acknowledgements:}

The authors gratefully acknowledge funding support from the EU Seventh Framework FP7-HEALTH \#602820 (MATHIAS).

1. Graves, S. A. et al. Novel Preparation Methods of ${ }^{52} \mathrm{Mn}$ for ImmunoPET Imaging. Bioconjug. Chem. 26, 2118-2124 (2015). 
2. Banci, L. Metallomics and the cell. Met. Ions Life Sci. 12, (2013).

3. Silva, A. C. \& Bock, N. A. Manganese-enhanced MRI: An exceptional tool in translational neuroimaging. Schizophr. Bull. 34, 595-604 (2008).

4. Antkowiak, P. F., Stevens, B. K., Nunemaker, C. S., McDuffie, M. \& Epstein, F. H. Manganeseenhanced magnetic resonance imaging detects declining pancreatic $\beta$-cell mass in a cyclophosphamide-accelerated mouse model of type 1 diabetes. Diabetes 62, 44-48 (2013).

5. Crossgrove, J. \& Zheng, W. Manganese toxicity upon overexposure. NMR Biomed. 17, 544-553 (2004).

6. Koretsky, A. P. \& Silva, A. C. Manganese-enhanced magnetic resonance imaging (MEMRI). NMR Biomed. 17, 527-531 (2004).

7. Silva, A. C., Lee, J. H., Aoki, I. \& Koretsky, A. P. Manganese-enhanced magnetic resonance imaging (MEMRI): Methodological and practical considerations. NMR Biomed. 17, 532-543 (2004).

8. W. Severin, G., W. Engle, J., E. Barnhart, T. \& Nickles, R. J. 89Zr Radiochemistry for Positron Emission Tomography. Med. Chem. (Los. Angeles). 7, 389-394 (2011).

9. Anderson, C. J. \& Ferdani, R. Copper-64 radiopharmaceuticals for PET imaging of cancer: advances in preclinical and clinical research. Cancer Biother. Radiopharm. 24, 379-93 (2009).

10. Moses, W. W. Fundamental limits of spatial resolution in PET. Nucl. Instruments Methods Phys. Res. Sect. A Accel. Spectrometers, Detect. Assoc. Equip. 648, S236-S240 (2011).

11. Dong, Y. \& Junde, H. Nuclear Data Sheets for A = 52. Nucl. Data Sheets 128, 185-314 (2015).

12. Wooten, A. L., Lewis, B. C. \& Lapi, S. E. Cross-sections for (p,x) reactions on natural chromium for the production of 52,52m,54Mn radioisotopes. Appl. Radiat. Isot. 96, 154-161 (2015).

13. Buchholz, M., Spahn, I., Scholten, B. \& Coenen, H. H. Cross-section measurements for the formation of manganese-52 and its isolation with a non-hazardous eluent. Radiochim. Acta 101, 491-499 (2013).

14. Buchholz, M., Spahn, I. \& Coenen, H. H. Optimized separation procedure for production of nocarrier-added radiomanganese for positron emission tomography. Radiochim. Acta 0, 893-899 (2015).

15. Pietrzyk, D. Anion exchange separations of metal ions in partially nonaqueous solutions. Retrosp. 
Theses Diss. Paper 2390, (1960).

16. Nelson, F., Murase, T. \& Kraus, K. A. Ion Exchange Procedures I. Cation Exchange in Concentrated $\mathrm{HCl}$ and $\mathrm{HClO} 4$ Solutions. J. Chromatogr. 13, 503-535 (1964). 